\title{
OS DOMÍNIOS DE INANNA: \\ PERMANÊNCIAS DE UM CULTO AO SAGRADO FEMININO NA MESOPOTÂMIA
}

\author{
The kingdoms of Inanna: permanecenses of \\ worship in the sacred feminine in Mesopotamia
}

\author{
Simone Aparecida Dupla*
}

\begin{abstract}
RESUMO
O presente artigo analisou o culto ao sagrado feminino entre os períodos de Uruk antigo e o paleobabilônico, através da deusa sumério/ babilônica Inanna/Ishtar, e justificou a sobrevivência desse culto tribal cuja característica principal foi a prática do hieros gamos como relação dessa divindade com o inconsciente coletivo. Inanna era um arquétipo mutante que, tendo sua origem na noite dos tempos, transformou-se em um culto estatal onde garantia o poder temporal do rei através do rito do casamento sagrado e sua própria sobrevivência devido às rupturas que ocorreram no culto à fertilidade.
\end{abstract}

Palavras-chave: sagrado feminino; hieros gamos; mito; inconsciente coletivo; Inanna.

\begin{abstract}
The present article was analyzed the sacred cult to the feminine enters the periods of Uruk and to old Babilonian, through the Sumerian/ Babilonian goddess Inanna/Ishtar, and justified the survival of this tribal cult whose main characteristic practice was it of it Hieros Gamos as relation of this deity with the collective unconscious. Inanna was one archetype mutant that having its origin in the night of the times it was changed into a state cult where guarantee the secular power of the king through the rite of the sacred marriage and its proper survival due the ruptures that had occurred in the cult the fertility.
\end{abstract}

Key-words: sacred feminine; sacred union; myth; collective unconscious; Inanna.

* Especialista em História, Arte e Cultura pela UEPG. 
O território que corresponde ao atual Iraque foi conhecido na antiguidade com o nome de Mesopotâmia, termo grego que significa "entre rios". Nessa região, encontramos registros que evidenciam o desenvolvimento do primeiro processo de urbanização, o qual G. Childe denominou de "Revolução Urbana" e que, na interpretação de Mário Leverani, ${ }^{1}$ foi multifacetado e profundo a ponto de mudar por completo a organização das sociedades humanas.

A passagem da vida nômade à sedentária veio acompanhada de diversas transformações e criações em distintos aspectos nesse território, entre elas a primeira forma de escrita da humanidade, a cuneiforme, cuja decifração foi realizada em 1803, pelas mãos do alemão Grofend, conforme destaca Jean Botteró, ${ }^{2}$ fato esse que colocou luz sobre a história das civilizações que se fixaram nesse espaço geográfico.

Nesse local, surgiu a religião mais antiga da humanidade de que se tem registros até o momento, cujas cosmogonias e hierofanias evidenciam o elemento feminino ocupando papel central na criação do universo e na organização da vida.

Assim, neste trabalho abordaremos elementos circunscritos acerca do sagrado feminino mesopotâmico, relacionando-o à sobrevivência do culto às deusas mães, na figura da deusa sumério/babilônica Inanna/Ishtar, haja vista que as características desse culto foram perpetuadas na cultura material e nos ritos praticados durante milênios na região do Antigo Oriente Próximo.

Inanna era a deusa do sexo e do amor, estando a ela associados também elementos relacionados à fertilidade, à prostituição e às batalhas, sendo conhecida também sob os epítetos de Deusa do Amor, Estrela da Manhã e Estrela da Tarde.

Essa divindade governava o sexo em três modalidades principais: o sexo como reprodução (tanto como sobrevivência quanto como energia criadora), o sexo como prazer (sensual ou selvagem) e ainda o sexo como sagrado (como meio de conhecimento e encontro com o divino). Inanna governou os habitantes da antiga Mesopotâmia e suas instituições sempre marcando seu território a partir de seu leito; contudo, era capaz de pegar em armas para defender seus amados e seu território. 
Governou diversos templos, grandiosos como o de Uruk, o E-anna, e estendeu seu culto a lugares mais distantes, como o Abgal, em Umma, o Duranki, em Nippur, e o Edilmuna, em Ur. Neles construiu sua casa com servos que a alimentavam, sacerdotes para entoar cantos, eunucos que prestavam serviços, sacerdotisas para cerimônias diversas, com seus faustosos guarda-roupas, joias e tecidos dos mais diversos lugares e fiéis que lhe traziam libações.

Esta pesquisa utilizou como fontes os mitos e literatura sumério/ babilônicos datáveis do período de Uruk Antigo ao Paleobabilônico. Os textos selecionados encontram-se na obra de Kramer e Wolkstein, Inanna, Queen of Heaven and Earth, ${ }^{3}$ na Antologia de poemas de Helena Barbas, nos Himnos sumerios de Federico Lara Peinado, entre outros.

Salienta-se que grande parte desse material é proveniente das cidades de Uruk, Nippur, Kish, Ur, Lagash e Isin, embora as fontes não estejam condicionadas a espaços temporais ou geográficos, pois não há uma precisão nas datas e milhares de tabuinhas de argila esperam ainda pelo seu tradutor. A história da Mesopotâmia está em um processo contínuo de reconstrução.

Suas ricas iconografias, presentes no interior de templos e palácios, hoje estão expostas em diversos museus como o Metropolitan, Brooklyn Museum e o Louvre, possibilitando a reconstrução de sua história. Entretanto, temos outras tipologias de fontes que possibilitam a reconstrução da história de Inanna: os contos, os hinos, os cantos e os mitos, sendo a última categoria a mais utilizada por aqueles que se dedicam a estudar a história dessa deusa.

As representações iconográficas de Inanna disponíveis são ricas e polivalentes e apontam que a imagem que o homem religioso mesopotâmico fazia de seus deuses era complexa e múltipla, elemento esse típico de uma sociedade dinâmica e polissêmica, como foi na terra entre rios.

A iconografia presente em cilindros e vasos revelou os símbolos ligados à divindade, como a roseta de oito pétalas e os leões subjugados a seus pés com a estrela de oito pontas sempre presentes nos relevos (ver Figura 1). Para os integrantes dessa sociedade, a roseta e a estrela referem-se a símbolos de fertilidade e fecundidade, ligados por dois extremos: o

3 WOLKSTEIN, Diane; KRAMER, S. N. Inanna: Queen of heaven and earth. New York: Harper \& Row, 1983. 


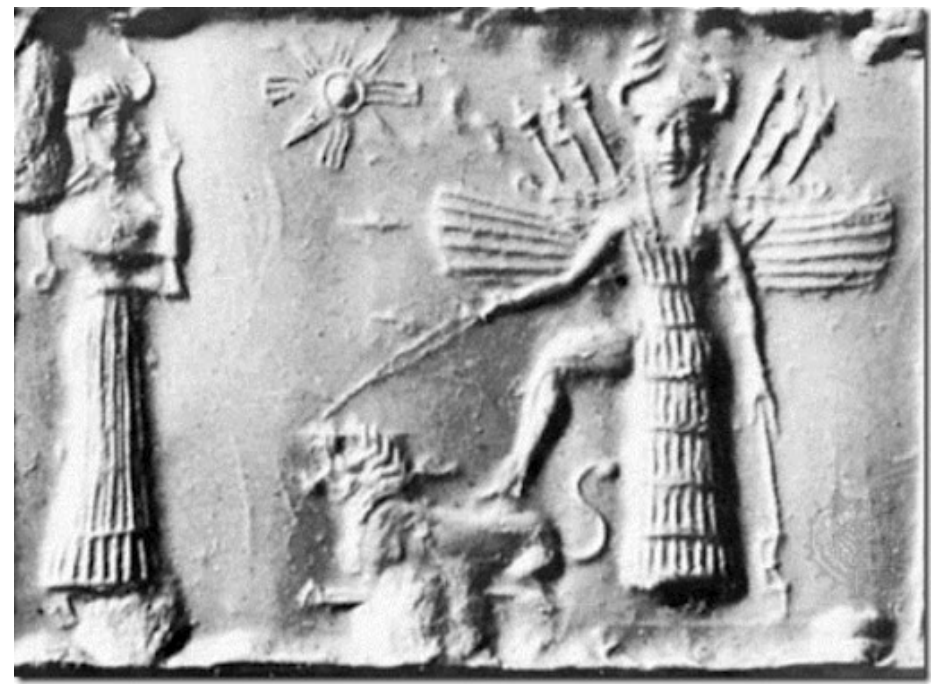

FIGURA 1 - MESOPOTÂMIA, PERÍODO AKKADIANO (2334-2154 A.C.), INSTITUTO ORIENTAL DA UNIVERSIDADE DE CHICAGO. Fonte: WOLKENSTEIN; KRAMER, p. 92.

céu e a terra, ou seja, se por um lado um elemento é povoado de estrelas, o outro, por sua vez, enche a terra de beleza e prosperidade.

O centro principal do culto a Inanna era a cidade de Uruk, no templo do E-anna, porém encontramos rituais celebrativos em sua homenagem em outras cidades, tais como Ur, Girsu, Kish e Zabalam, mas sua influência foi além das fronteiras da Mesopotâmia.

Samuel Noah $\mathrm{Kramer}^{4}$ nos informa que inicialmente o culto a essa divindade feminina era de origem tribal e eminentemente agrária, tornando-se, mais tarde, a condição de um culto estatal, porém suas práticas ritualísticas mantiveram-se as mesmas, como revelam os documentos escritos.

Muitos dos mitos, hinos e orações que foram criados para cultuar essa divindade se encontram registrados em tabuinhas de argila cuja sobrevivência contribuiu para que a história dessa deusa ficasse conhecida até a atualidade.

4 KRAMER, S. N. Le Rite de Mariage Sacré Dumuzi-Inanna. Revue de l'Histoire des Religions, v. 181, n. 2, p. 121-146, 1976. 
Uma das principais sobrevivências do culto a Inanna foi o hieros gamos, que consistia no casamento ritual entre a divindade e um representante da humanidade. Era através da relação sexual entre a divindade e o representante da humanidade que se mantinha o equilíbrio entre os poderes temporais e espirituais.

De acordo com Mircea Eliade, ${ }^{5}$ o "universo mental dos mundos arcaicos não chegou até nós dialeticamente nas crenças explícitas dos indivíduos, mas conservou-se nos mitos, nos símbolos e costumes que, apesar de todo gênero de degradação, deixam ver ainda claramente o seu sentido original".

Este autor foi um dos estudiosos que trabalhou com elementos relacionados ao sagrado e seus conceitos mitológicos e simbólicos no mundo antigo, sendo que, para ele, o mito é entendido na atualidade por etnólogos, sociólogos e historiadores das religiões como "tradição sagrada, revelação primordial, modelo exemplar". ${ }^{6}$ Acreditamos, portanto, que essa forma de narrativa é uma produção cultural, fruto da atividade humana, ligada a uma realidade sócio/cultural/temporal específica.

Henrietta $\mathrm{McCall}^{7}$ considera que o mito pode ser interpretado de várias maneiras: representar forças cósmicas; narrar ou refletir sobre fatos históricos, sejam estes batalhas, romances ou um ato diplomático; fazer menção ao regresso de estátuas de culto; como uma fórmula cultual a ser recitada a cada festividade ou, ainda, relembrar/reencenar os ciclos da natureza. A partir dessa classificação apresentada pela autora, pode-se dizer que a função do mito é dinâmica como a sociedade da qual ele faz parte ou o adotou.

Assim, o mito não deve ser compreendido fora do seu contexto sociorreligioso original, uma vez que o fenômeno religioso, por estar manifestado na história, é limitado e condicionado por ela (imagens e símbolos), pois esse era visto pelos homens como uma categoria do real.

Por conseguinte, é preciso lembrar que, embora o mito esteja condicionado ao tempo e, consequentemente, à história, este produz rupturas no Tempo Comum, ou seja, no tempo cronológico, proporcionando uma

5 ELIADE, Mircea. Tratado de história das religiões. São Paulo: Martins Fontes, 2008.

p. 16 .

6 ELIADE, op. cit., 2008, p. 9.

7 McCALL, Henrietta. Mitos da Mesopotâmia. São Paulo: Moraes, 1999. p. 74. 
abertura para se entrar no Tempo Sagrado ou Grande Tempo. ${ }^{8}$ Este, a partir de então, reatualiza o Tempo Sagrado, abrindo uma fenda para um tempo a-histórico, onde espaço e tempo não possuem mais nossa concretude convencional e onde os níveis de consciência se alteram, deixam a densidade da realidade para vibrar em movimentos e planos mais sutis.

Segundo Eliade, "a principal função do mito consiste em revelar os modelos exemplares de todos os ritos e atividades humanas significativos: tanto a alimentação ou o casamento, quanto o trabalho, a educação, a arte ou a sabedoria". ${ }^{9}$ Estas atribuições são perceptíveis tanto nos principais textos que se referem à divindade como nos hinos dedicados a ela. Portanto, o mito na sociedade mesopotâmica é também um arquétipo no sentido de modelo platônico.

Além disso, ao relacionar o mito ao conceito junguiano de inconsciente coletivo, percebe-se que a sobrevivência do culto e de algumas de suas características nas sociedades em tempos e espaços distintos deve-se ao fato de Inanna estar ligada às estruturas desse inconsciente, sendo, portanto, um arquétipo.

Para Jung, o inconsciente coletivo "é uma parte da psique que pode distinguir-se de um inconsciente pessoal pelo fato de que não deve sua existência à experiência pessoal". ${ }^{10} \mathrm{E}$ os arquétipos como conteúdos desse inconsciente coletivo, segundo o autor, são determinadas formas da psique que estariam presentes em todos os tempos e lugares, daí sua sobrevivência independente do espaço físico/temporal em que o homo religious exista. É importante salientar que o mito refere-se sempre a um discurso sobre a realidade e o rito serve para atualizá-lo, por isso as adaptações que surgiram a partir do terceiro milênio, período em que outras formas de economia e organização começam a entrar em cena.

Segundo Jung, os arquétipos transformam-se em formas conscientes (apenas parcialmente) e são transmitidos segundo a tradição, portanto, os conhecimentos esotéricos e a tradição (ou um em função do outro) são expressões típicas para a transmissão de conteúdos coletivos que originalmente provêm do inconsciente.

8 Expressão usada por Mircea Eliade.

9 ELIADE, Mircea. Aspectos do mito. Rio de Janeiro: Perspectivas do Homem/Edição 70, 1963. p. 14-15.

10 JUNG, C. G. Os arquétipos e o inconsciente coletivo. 6. ed. Tradução de Maria Luiza Appy, Dora Mariana R. Ferreira da Silva. Petrópolis: Vozes, 2008. p. 53. 
O mito, sendo uma narrativa sagrada e/ou estatal, deve ser rememorado, lembrado por todas as gerações, e são esses documentos orais, textuais ou arqueológicos que nos permitem compreender essas culturas, seus universos mentais e narrar por nossa vez sua história.

A religião e a religiosidade mesopotâmica mantiveram presentes seus principais mitos nas novas formas de culto que, assim como a sociedade, se dinamizaram após a urbanização, buscando, dessa forma, integrar o florescente ambiente citadino às antigas manifestações religiosas do campo originadas com a agricultura, posteriormente unida à pecuária, preservando assim uma tradição religiosa milenar.

\section{Religião e religiosidade na terra "entre rios"}

Na Mesopotâmia, era a religião que estabelecia a identidade entre seus habitantes, era ela que mantinha os indivíduos unidos, independente da língua que falassem ou do território que ocupassem.

A religião dessa cultura esteve relacionada ao seu espaço físico e às questões de sua sobrevivência, como, por exemplo, a terra, de onde o homem mesopotâmico via a vida brotar, criando e recriando as condições de subsistência. A religião mesopotâmica foi reflexo de mentalidade e cultura e também foi espelho do universo que a circundava, dos sonhos que se projetavam para além da cidade murada ou dos campos cultivados.

Desde os primórdios, os homens dessa sociedade construíram seu mundo como reflexo do mundo de seus deuses, por isso o antropomorfismo foi uma das principais características de suas crenças religiosas, ligado às impressões e expressões fisiológicas e eróticas das divindades. Segundo Botteró:

La religión, en particular, está unida, y por infinitos lazos viscerales, a la cultura entera, a la mentalidad, a la visión de las cosas y a los sentimientos que éstas hacen nacer, a los infinitos detalles de la vida cotidiana de seos fieles, y que ya no son, o nunca ha sido, espontáneamente los nuestros, incluso si debemos reconocerlos en el origen de los nuestros. ${ }^{11}$ 
O universo religioso daquela antiga civilização era composto por inúmeros deuses que regiam todos os setores da vida dos habitantes dessa terra, os quais eram intermediados pelos sacerdotes, executores dos cultos e procuradores dos deuses no plano terreno.

Os deuses eram seres construídos à imagem e semelhança do homem mesopotâmico, no entanto, eram superiores a eles em todos os sentidos, tanto positiva quanto negativamente. Esses se originaram do modelo humano em gerações sucessivas, ${ }^{12}$ modificaram-se, adaptaram-se aos momentos que se apresentavam e assim sobreviviam com maior ou menor êxito através do tempo. Como nos lembra Jung, as imagens têm por função "atrair, convencer, fascinar e subjugar. Elas são criadas a partir da matéria originária da revelação e representam a sempre primeira experiência da divindade". ${ }^{13}$

Era nesta perspectiva que os deuses mesopotâmicos existiam e as iconografias mostram um deus a esbanjar os seus poderes e a sua superioridade. Os hinos para eles criados demonstram como manipulavam e controlavam tudo ao seu redor, eles estavam sempre propensos a subjugar os inimigos ou fiéis, a fascinar os mortais ou os iguais com sua beleza e sedução, a atrair humanos e divinos com seus encantos ou com suas artimanhas.

A religiosidade mesopotâmica, por ser reflexo do mundo ao seu redor, manteve em suas representações religiosas os cultos ancestrais da vegetação e dos ciclos agrários; dessa forma, constituiu um papel importante para as mulheres, uma vez que algumas divindades femininas mantiveram-se ligadas aos mais diversos campos de conhecimento dessa sociedade.

Antonio Ramos dos Santos ${ }^{14}$ defende a ideia de que o culto à fertilidade remonta à época neolítica, sendo praticado em ritos durante os ciclos agrícolas. Pode-se crer então que as características referentes ao culto às Deusas-Mães sobreviveram por se tratarem de arquétipos. ${ }^{15}$

Jung também defendia a ideia de que o inconsciente coletivo canalizado para ideias dogmáticas de natureza arquetípica flui como uma

\footnotetext{
15 Podemos acrescentar que suas raízes ou função primeva permaneceram inalteradas, que sobreviveram no inconsciente coletivo, já que, ainda segundo Jung, os arquétipos tornam-se conscientes apenas parcialmente. Perpetuados no inconsciente coletivo, os mitos adaptam-se à situação social vigente, guardando em sua essência as características de seus arquétipos primordiais.
}

p. 70 .

12 Id., p. 83.

13 JUNG, op. cit., p. 20.

14 SANTOS, Antonio Ramos dos. O sagrado na Balilónia antiga. Lisboa: Cadmo, 1997, 
corrente controlada no simbolismo e no credo. ${ }^{16} \mathrm{E}$ isto se aplica à religiosidade mesopotâmica, pois os ritmos rituais estetizavam e produziam um êxtase coletivo durante as cerimônias e uma dependência durante a vida dos fiéis, vinculando-os desde sempre aos seus deuses através dos elementos de cultura material e imaterial.

Os habitantes da "terra entre rios" estavam envoltos em manifestações femininas do divino, caracterizadas nas relações com o modo de produção e reprodução da sociedade. A lista de Shurupak, ${ }^{17}$ por exemplo, contém mais de quinhentos e sessenta nomes de divindades masculinas e femininas, mostrando a infinidade de cultos e ritos que possivelmente eram praticados nessa civilização. Nesta lista, Inanna, objeto do presente trabalho, aparece na terceira coluna, antecedida por An (deus do Céu) e Enlil (deus dos Ventos).

As divindades femininas estiveram ligadas a inúmeros campos de atuação e de pensamento do homem mesopotâmico, como, por exemplo, na terra onde brota a vida, de cujo mistério da criação as mulheres fazem parte, pois a concepção era tida como um mistério sagrado e as mulheres eram responsabilizadas pela abundância das colheitas, "pois elas conhecem o 'mistério' da criação, uma vez que a vida também brota das mulheres". ${ }^{18}$

Segundo Felicien Challaye,

[...] as divindades cultuadas na região mesopotâmica variam de uma cidade para outra. Estas divindades locais são, sobretudo, femininas, réplica dessa grande deusa a Mãe Universal, que foi venerada do Mediterrâneo ao Golfo de Bengala por egeus, asianos e dravidianos. Tiamat, divindade do oceano, Nana ou Nina [Inanna], protótipo da Ishtar babilônica. ${ }^{19}$

O contingente de oficiantes femininos dos templos da Mesopotâmia também atesta a importância das divindades femininas nessa sociedade.

16 JUNG, op. cit., p. 21.

17 Vestígios de cultura material encontrado nas escavações de Fâra/Suruppak e Tell Abu-Salabih, datados de aproximadamente 2600. A lista tem esse nome devido ao local onde foi encontrada.

18 ELIADE, Mircea. História das crenças e ideias religiosas. São Paulo: Martins Fontes, 1979. p. 123 .

19 CHALLAYE, Félicien, Pequena história das grandes religiões. 2. ed. Tradução de Alcântara Silveira, São Paulo: Ibrasa, 1967. p. 130. 
Nelas encontramos, segundo os dados de Federico Lara Peinado, as nin-dingir (senhora/divindade) ou alto-sacerdotisas, as sal-dingir (mulher do deus) e ainda as $n u$-gig (hierodulas), que povoavam os recintos do templo. ${ }^{20}$

As deusas fundiam-se em suas características fisiológicas e simbológicas com mulheres, propiciando a influência destas em diversas relações sociais e de poder das culturas mesopotâmicas.

\section{Inanna: a deusa da vida e das infinitas manifestações da vida}

A princípio, a Inanna foi concedida a personificação de Grande Mãe, pois ela era a responsável pela abundância das colheitas, assim como as dádivas e os favores por ela eram distribuídos. ${ }^{21}$ Ottermann aponta que os primeiros documentos sobre ela foram escritos por volta de 3000 a.E.c. e são provenientes da cidade de Uruk. Tais documentos

[...] atestam Inanna como a deusa principal da cidade, e apesar das primeiras mudanças que seu perfil sofreu nos interesses do sacerdócio (que detinha tanto o poder religioso quanto o poder econômico-político), permanece nítido seu caráter de uma divindade do tipo da "Grande Deusa", provindo dos tempos neolíticos. ${ }^{22}$

Outra evidência da antiguidade do culto é revelada por Kramer, que mostra o culto a Inanna em seu rito de fertilidade: o hieros gamos pode ser

20 PEINADO, Federico Lara. Himnos sumerios. Madrid: Molina, 1988. p. XXXIII.

21 Acreditamos que Inanna não foi apenas a deusa do amor sexual, ou do amor livre, como simplificaram muitos autores. Ela estava relacionada também ao modo de produção e reprodução daquela sociedade. O fato de ser uma deusa de origem agrária comprova isto, uma vez que os ritos de fecundidade e fertilidade exigem uma prática sexual que visa não apenas à reprodução humana e animal, mas também à prosperidade material, à satisfação instintiva e ao encontro com o sagrado e à hierofania. $\mathrm{O}$ ato sexual nesses cultos de origem agrário era, portanto, um ato integrador.

22 OTTERMANN, Monika. Morte e ressurreição na Suméria: a "Descida ao Inferno" de Inanna e de Dumuzi. Processos de posse e perda de poderes divinos e humanos. Oracula, São Bernardo do Campo, v. 2, n. 3, p. 4, 2006. 
datado da primeira metade do terceiro milênio, porém mesmo "antes destes textos não é de se duvidar que os teólogos e poetas sumerianos tivessem conhecimento de uma tradição histórica segundo a qual Dumuzi desposava ritualmente Inanna na cidade de Erech". ${ }^{23}$

Essa mesma opinião é partilhada por Botteró, segundo ele, "un mito, un ritual, tienen tras de sí - y a su lado - siglos de tradición oral: tácita, inaprensible, y de la que jamás sabremos nada"; 24 a tradição oral, portanto, precede a escrita. Os textos mesopotâmicos começam sempre com uma repetição, o que dá ideia de uma tradição oral, anterior à cultura escrita e cujas características foram perpetuadas pelos poetas/sacerdotes.

Ao falarmos em culto agrário, nos reportamos a uma de suas principais características, a relação sexual sagrada (hieros gamos), pois Inanna era a deusa da cópula por excelência; em função disso, ela teve uma de suas características ligadas à prostituição. Entretanto, vale lembrar que na cultura dos mesopotâmicos essa prática era considerada um ato sagrado, pois estava presente nas Medidas Sagradas em duas modalidades: a prostituição no templo e a prostituição na taverna. As Medidas Sagradas estavam relacionadas à forma como o homem mesopotâmico via o mundo e tecia suas relações sociais, uma vez que elas estavam relacionadas às funções sociais ou psicológicas daquelas culturas.

O hieros gamos garantia o poder temporal do rei, mas também garantia a sobrevivência de um culto ancestral. A sacerdotisa que tomava o lugar de Inanna no casamento sagrado não era apenas a representante da divindade, não estava apenas no lugar dela: era o receptáculo da divindade, o instrumento que permitia o contato não apenas espiritual, mas também mensurável entre o sagrado e o profano, entre o rei e a deusa.

$\mathrm{Na}$ época neossumeriana (2100-2000), os reis identificavam-se com Dumuzi ${ }^{25}$ praticando a hieros gamia como seu representante, rememorando-a anualmente por meio do casamento sagrado com Inanna. Diversos reis

23 KRAMER, S. N. Le rite de mariage Sacré Dumuzi-Inanna. Revue de l'Histoire des Religions, v. 181, n. 2, p. 122, 1976.

24 BOTTERÓ, op. cit., p. 46. (a)

25 Em acádio, Tammuz foi um soberano arcaico e em parte lendário, pois a mitologia o coloca como primeiro amante de Inanna, seu consorte durante o hieros gamos; consta como terceiro rei de Uruk na Lista de Reis. 
cantaram hinos a Inanna durante a festa do hieros gamos, entre eles Iddin-dagan, ${ }^{26}$ Gudea $^{27}$ e Su-Su'em. ${ }^{28}$

Além disso, vários reis foram objeto de hinos que referenciavam sua pessoa como o "santo esposo de Inanna", no hino a Enlilbani, ${ }^{29}$ "destinado ao deleite de Inanna", como o rei Shulgi, ${ }^{30}$ "desejado para esposo de Inanna", no caso do rei Lipit-Ishtar. ${ }^{31}$ Dumuzi tornou-se uma espécie de avatar representado pelos reis que se sucederam no trono da Mesopotâmia, encarregados de satisfazer as exigências da Jovem Senhora e garantir prosperidade, fecundidade e fertilidade em todos os aspectos.

Como mostra o trecho a seguir, retirado de um balbale ${ }^{32}$ de Inanna:

[...] Para el rey, el elegido de tú corazón, para Dumuzi, el hijo de Enlil, decretará (producir) manteca y leche en la Casa del establo decretará órdenes de abundancia en el redil.

Prolonga los días de Eshme-Dagan que la oveja madre críe con cuidado a su corderillo! Que pueda admirar a mí esposo! ${ }^{33}$

Um canto do reinado do rei Su-Su'em (2037-2029) e recitado durante a celebração do matrimônio sagrado apresenta-se a nós cheio de volúpia e erotização.

Oh querido mio, caro a mi corazón,

el placer que me das es Dulce como la miel!

$[\ldots]$

Tu corazón, yo sé cómo dilatarte el corazón: dame en nuestra casa, león mio, haste que despunte el día.

Y tú, puesto que me amas, dame, te lo ruego, mi león, tus caricias.

26 Terceiro rei de Isin (1974-1954).

27 Ensi da cidade-estado de Lagash que reinou entre 2144-2124 aEc.

28 Rei da terceira dinastia de Ur (2037-2029).

29 Décimo rei de Isin 1860-1837.

30 Segundo rei da terceira dinastia de Ur (2093-2046).

31 Quinto rei de Isin (1934-1924).

32 Composição hino/poética, abarcou desde a glorificação dos feitos dos monarcas, deuses, cantos de amor. Sua recitação era acompanhada de música.

33 PEINADO, op. cit., p. 30. 
Mi soberano divino, mi señor y mi protector, mi Su-Su'em, que regocija el corazón de Enlil, dame, te lo ruego, tus caricias.

Pon tu mano ahí, si quieres, en ese oculto rincón, Dulce como la miel. ${ }^{34}$

As fontes também revelaram a ligação dessa divindade com os conflitos armados que estiveram presentes nessa civilização e intensificados após a unificação territorial, realizada pelo rei Sargão I (2340-2284), de Agadé.

A partir de então, o rei ficou submetido à autoridade da deusa, tornando-se um esposo obediente, um grande herói que luta por e para ela, como pode ser visto no canto citado por Peinado:

Mi señora, él (Enlil) te ha lo dado como esposo obediente (para que) te alegres con él; [...]

Inanna, tú has concedido tú fuerza a él, al rey:

Ama-ushumgal-anna ${ }^{35}$ se te muestra con luminoso esplendor. Cuando marcha contra el país rebelde, al lejano país de las montañas, pasa los días en el tumulto de la lucha. ${ }^{36}$

Inanna tornou-se a companheira do rei e o acompanhava nos campos de batalha, não só como sua protetora, mas também como líder do exército, como mostra um canto destinado a ela pelo rei Gudea, no qual a chamava de Nin-me, a Senhora da Batalha.

Segundo o documento de Iddin-Dagan, ${ }^{37}$ a divindade possuía uma estátua de culto ornada com joias e manto real. Era invocada pelos guerreiros, elevada à condição de patrona dos exércitos, pois o texto diz que sem dúvida alguma os jovens valorosos (guerreiros) a invocavam, pois Inanna é aquela que causa pavor durante a luta, aquela que faz tremer o céu, portanto, todos a ela prestam homenagens, os homens, os deuses, animais, toda a natureza se curva diante da pura Inanna. ${ }^{38}$ 
Inanna transformou-se de uma frágil ${ }^{39}$ deusa em uma divindade com poderes bélicos, uniu beleza, fertilidade e soberania material/espiritual numa só pessoa, crescendo em poder e, consequentemente, em influência. Alguns textos a chamam de hierodula ${ }^{40}$ do céu e, ao que tudo indica nos cantos, seus ritos ocorriam a cada lua nova, uma espécie de esbat, um ritual mensal, e uma grande festa anual. Segundo o mesmo documento, essa cerimônia lunar congregava todos os deuses, como destaca o trecho abaixo:

Con An ella os toma (os MEs), se sienta en el gran trono, con Enlil ella fija los destinos para su país.

Cada mes, con la luna nueva, a fin de cumplir los me, los dioses del país se congregan a su alrededor, los dioses Anunna se arrodillan ante ella, acuden con ofrendas y oraciones, y recitan la plegaria para todas las tierras. Mi señora decide con justicia las causas ne el país, [Inanna] da justas sentencias [en el] país.

Sus "cabezas negras" acuden ante ella $[\ldots]^{41}$

Inanna era a deusa diante da qual homens e deuses desfilavam trazendo presentes, oferendas e petições. Também era portadora do poder de resolver querelas e por isso recebeu o título de Senhora da Justiça, pois ela "conhece o justo e reconhece o malvado, condena o malvado, destroça o perverso, mas ao justo lança um olhar favorável e lhe dá um bom destino". ${ }^{42}$

O dinamismo da personalidade de Inanna tornou-a a deusa mais popular da antiguidade mesopotâmica. Cheia de vontades, mostrou-se capaz de sobreviver e influenciar uma sociedade multicultural. Arrogante muitas vezes com os deuses, os quais vencia como mostra um balbale, ${ }^{43}$ pergunta

39 A fragilidade da deusa pode ser percebida nas linhas do mito A árvore de Hullupu, onde a divindade precisa de ajuda para desocupar a árvore que serviria para seu trono e sua cama. Para mais detalhes do mito: WOLKSTEIN, Diane; KRAMER, S. N. Inanna: Queen of heaven and earth: her stories and hymns from sumer. New York: Harper \& Row, 1983.

40 Aquela que pratica o sexo sagrado, prostituta sagrada.

41 PEINADO, op. cit., p. 36.

42 Id., p. 40.

43 Gênero literário cuja recitação era acompanhada de instrumentos musicais. 
se algum deus pode comparar-se a ela e diz ainda o poeta: "Los dioses son bandadas de (temerosos) pajáros, (pero) yo soy reina, yo!". ${ }^{44}$

A sede de poder e glórias de Inanna parece ilimitada, os mitos revelam que ela vai conquistando aos poucos todos os domínios, pois conquistou os Mes (Medidas Sagradas) do deus Enki, o Eanna do deus An e até mesmo o Grande Abaixo ou Mundo Inferior da deusa Erishkigal, embora este último apenas parcialmente e por um preço bem alto.

A Senhora do Entardecer era sublime, cantavam os poetas, se alegrava quando os homens faziam amor e quando se exercitavam na guerra, possuía características dos deuses maiores, como Utu e Nannar, quer dizer, era tão resplandecente quanto o sol ao alvorecer e como a lua à noite.

As oferendas a Inanna eram as mais variadas, eram acesos incensos nos terraços ou em "lugares acolhedores" ou, ainda, nos corredores das muralhas. Normalmente, eram colocados no alto para encher o céu com perfumes, imolavam-se ovelhas, purificavam os altares para as oferendas, onde encontrava-se todo tipo de libações. ${ }^{45}$

Esta manifestação de agradecimento à deusa com as oferendas remonta novamente aos primórdios do culto, pois se ofereciam em agradecimento pela abundância e, em desejo de prosperidade, ofertavam manteiga, frutas, cerveja de trigo, mel, vinho e flor de farinha, ${ }^{46}$ produtos da terra, dádivas da própria deusa da vida. A flor de farinha indicava que os campos estavam em flor, que a colheita seria favorável, assim como os outros produtos indicavam prosperidade, fertilidade e fecundidade tão caras ao homem mesopotâmico em sua vida material e demonstração de prosperidade que refletia na vida espiritual.

Era na festa do hieros gamos que o culto a Inanna encontrava o seu ápice, principalmente no momento do Grande Rito: o Akitu, pois os documentos fazem menção a esta festa do Ano Novo, onde se comemorava a abundância das colheitas, o êxito nas batalhas e onde a hierofania recriava novamente o mundo e o homem tornava-se contemporâneo destes eventos.

Durante esse festival, havia a licenciosidade sexual, orgias sagradas e profanas, sendo que o sexo desde épocas ancestrais era uma maneira de

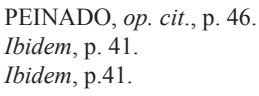


encontro com o sagrado e de comemorar a vida, pois se acreditava que era através dele que a vida acontecia na Mesopotâmia, tanto humana como divina.

A câmara nupcial devia ser arrumada, purificada de acordo com os ritos, por isso, com cantos, música, recitações e oblações o leito da Jovem Senhora era adornado, dispostos lençóis e cobertores para que o lugar se tornasse aconchegante.

E sendo a deusa do sexo ou do amor livre, como se referem alguns autores, Inanna mostrava o caminho, ensinava os segredos do "abraço sagrado", ela se purificava, banhava-se com sabão, untava o corpo com óleo perfumado e esperava ansiosa no leito. $O$ rei chegava também ansioso por compartilhar o leito da deusa e se unia a ela no "abraço sagrado" e, como diz o canto: "se regocija con el sagrado abrazo. La pura Inanna después de haberse regocijado en el diván con el abrazo ritual, la Señora, regocijada en el abrazo ritual, se entretiene con él en aquel diván. (Ella dice) a Iddin-Dagan: 'Tú eres ciertamente mí amado"”.47

Mas a união sexual promovida por Inanna não era apenas lânguida e voluptuosa, afinal ela era a "vaca selvagem", a "doadora da vida", ${ }^{48} \mathrm{o}$ ato sexual foi também desejo ardente, insaciável, pois o arado abre caminho na terra virgem, e Inanna ordena: "are minha vulva". Portanto, era também o coito selvagem da sobrevivência, dos primeiros ritos da fertilidade e fecundidade, desse arquétipo ancestral que é o instinto sexual, presente nas formas de reprodução e produção da vida tribal.

É importante dizer que, embora instintivo, carnal, o sexo não era uma prática violenta; ao contrário, a violência sexual era abominada na Mesopotâmia e possuir uma mulher sem o consentimento da mesma foi ato considerado imoral e sujeito a punições, mesmo entre os deuses. Dois exemplos disso dizem respeito a textos mitológicos. O primeiro diz respeito ao deus do Ar, Enlil, que violentou a deusa Ninil. Este ato foi considerado imoral, mesmo para um deus, e, embora Enlil fosse soberano dos deuses, foi banido para o mundo inferior.

Outro exemplo diz respeito a Inanna: um mito, cuja placa encontra-se no museu de Istambul, relata a vingança da divindade, que fora violentada

47 Ibidem, p.44.

48 Ibidem, 1988, p.46. 
por um jardineiro. Segundo o mito, a deusa, cansada por ter atravessado o céu e a terra e ainda viajado por lugares distantes como o Elam, deitou-se no jardim de Shukallituda, no qual um jardineiro a espiava do outro extremo. Quando Inanna adormeceu, o jardineiro "possuiu-a, beijou-a e regressou ao extremo do seu jardim"; ao acordar na manhã seguinte, a deusa ficou horrorizada e para vingar-se de quem a possuiu, como não o encontrasse, transformou todas as águas em sangue. Inanna causou mal à terra toda, por causa do seu sexo. ${ }^{49}$ Inanna se vingou, transformando as águas em sangue.

$\mathrm{O}$ mito, enquanto modelo exemplar, dita normas de conduta. A mulher não deve ser forçada; ao punir o opressor ou vingar-se de toda sociedade quando não encontrado, Inanna mostra que não pode ser ultrajada onde deve ser cultuada: seu sexo, e isso se estendia às mulheres mesopotâmicas, pois até mesmo os códigos de leis compreendiam medidas a esse respeito. Há casos em que até mesmo as escravas concubinas faziam valer seu direito de serem assistidas material e conjugalmente por seus senhores.

Assim, pode-se perceber de que forma o culto estava integrado à realidade mesopotâmica, interligava a religiosidade, a economia e a política, além de interferir nas práticas sexuais. A Corte de Inanna e Dumuzi apresenta essas características estreitamente ligadas à vida daquela sociedade.

Inanna foi descrita em um hino babilônico escrito no início do segundo milênio como uma deusa insaciável, segundo ele: "sesenta y sesenta hombres, uno trás outro, pueden gozar de su sexo: ellos quedan esgotados, pero no Ishtar!". ${ }^{0}$

Essa divindade insaciável recebeu vários nomes nas diversas cidades do Antigo Oriente Próximo devido a questões linguísticas e relações de poder, convertendo-se na deusa mais importante de toda Ásia Ocidental ${ }^{51}$ talvez porque, como lembra Eliade, a "sexualidade nunca foi 'pura' com imaginava Freud [...] e exceto para o mundo moderno, a sexualidade foi sempre e em toda parte uma hierofania, e o ato sexual, um ato integral (logo, também um meio de conhecimento)". 52

49 KRAMER, S. N. A história começa na Suméria. Portugal: Publicações Europa-América, 1997, p. 98.

$50 \quad I d .$, p. 92.

51 McCALL, Henrietta. Mitos da Mesopotâmia. São Paulo: Moraes, 1999. p. 25.

52 ELIADE, Mircea. Imagens e símbolos: ensaio sobre o simbolismo mágico-religioso. São Paulo: Martins Fontes, 2002, p. 10, grifo do autor. 
A união sexual de Inanna e Dumuzi descrevia em detalhes posições e carícias que eram praticadas. Há nos textos uma expressão de sentimentos humanos quase tangíveis, insinuantes, indutivos, como um convite e um exemplo à comunidade, o modelo exemplar de que fala Eliade, uma sensualidade nas frases: "Com mãos doces como mel, com pés escorrendo mel, fazia-me coisas doces! Os seus membros sendo doces, doce de mel, ele fazia-me coisas doces. Oh meu amado que de repente fizeste coisas doces, a tudo dentro de mim até ao umbigo", ${ }^{33}$ ou ainda:

\author{
Depois, no leito, nos membros sagrados, \\ Ele faz a rainha rejubilar, \\ Depois, no leito, nos membros sagrados, \\ Ele faz a rainha rejubilar \\ Por sua vez, ela acalmou-lhe o coração. \\ Ali no leito. ${ }^{54}$
}

A importância dessa divindade (Inanna) dizia respeito não só ao modus vivendi do homem mesopotâmico, sua vida material, mas também ao que se relacionava às suas representações coletivas em formas definidas.

Uma dessas formas foi o culto ao sagrado feminino em uma de suas manifestações, o Ritual do Abraço Sagrado, o hieros gamos de Inanna e sua contraparte representada pelo rei, o qual encarnava o rei/pastor Dumuzi durante a cerimônia. Daí a influência da divindade em diversos aspectos da sociedade que floresceu entre os rios Tigre e Eufrates.

\title{
Considerações finais
}

Percebeu-se ao longo da análise das fontes que a presença do sagrado feminino permeou a economia (rural e urbana) e a política (interna e externa, questões militares e administrativas), mostrando que havia uma

p. 3 .

53 BARBAS, Helena. A saga de Inanna (antologia de poemas). Lisboa: 2004 (revisão 2006).

$$
54 \quad I d ., \text { p. } 18 .
$$


ciranda cultural e temporal no/do culto, pois ele ligava as práticas de piedade popular (sua origem tribal) às legitimações das elites (estatais e religiosas).

Inanna foi uma divindade ligada a distintos campos de ação do homem religioso mesopotâmico, por ter sido uma deusa uraniana, como indica seu nome: Senhora do Céu tem como uma de suas principais características a soberania, no entanto, o modo de governar de Inanna possuía atributos singulares, pois ela não governava apenas os homens, os deuses e a natureza, governava a força motriz que os fazia viver e sobreviver sobre a terra.

Os domínios de atuação da deusa Inanna sobreviveram às mudanças de reis e de clima. Resistiu na mentalidade coletiva como arquétipo mutante, modelo exemplar, sagrado entrelaçado ao profano, mundo divino reflexo do humano e humano do divino. Mostrou sentimentos tão humanos, como o ódio, o amor, a vingança, a volúpia, o desejo, mostrou sua face de mulher caprichosa e arrogante, escolheu seus amantes de sangue nobre ou plebeu, escolheu suas joias e seus reinos, estendeu seus territórios físicos e espirituais. Tais características se estenderam às mulheres e influenciaram seu modo de vida, tornando-as uma espécie de extensão da personalidade da divindade.

Manteve sua essência de culto agrário mesmo no contexto do culto estatal, os documentos escritos passaram do sumério para o acádio e a força dessa tradição sobreviveu em cultos reencenados no decorrer de milênios.

As relações sexuais na Mesopotâmia possuíam um estatuto que nossa concepção ocidental cristã desconhece e, portanto, torna difícil a apreensão.

Inanna era a deusa do sexo por excelência, sua sexualidade ao mesmo tempo humana e divina ditava regras comportamentais, estendia às mulheres comuns o prazer divino, uma vez que servia de modelo à sociedade. Era possível, portanto, que o sexo servisse como forma de encontro com o sagrado, uma forma de prestar culto à divindade.

A extensão e a durabilidade temporal desse culto estiveram associadas às suas relações com as classes populares, campesinos e citadinos que alimentavam uma crença na deusa regente da vida e da morte. Essa crença popular, de origem tribal, foi perpetuada através das festas, dos hinos, dos templos e possivelmente também permitiu que algumas de suas características sobrevivessem para além das fronteiras espaçotemporais, para além da sociedade material extinta posteriormente. 
Acreditamos que as influências exteriores e interiores nas religiosidades mesopotâmicas não foram apenas apreendidas ou apropriadas. Essas influências foram filtradas, diluídas e transformadas pelo sistema simbólico templário para serem assimiladas e/ou aceitas (total ou parcialmente) pela comunidade. Mas ao mesmo tempo em que as gerenciava, ele também irradiava, propagando sua influência a outras culturas dentro e fora dos limites territoriais, mantendo sua presença intercultural, temporal e geográfica, além de ceder aos apelos da religiosidade popular, talvez até mesmo por uma questão de sobrevivência desse sistema.

A experiência coletiva nos festivais do hieros gamos que ocorriam na festa de Ano Novo, cerimônia que renovava o mundo e encenava e rememorava rituais de fertilidade, fecundidade e prosperidade foram essenciais à existência e à subsistência do homem religioso mesopotâmico, assim como do culto a Inanna.

As fontes sobre essa divindade são um enorme campo de estudos sobre os mais variados temas, seja no ramo da patriarcalização da religião, da sexualidade na antiguidade ou do sagrado feminino. Sua iconografia e literatura têm muito a contar sobre a cultura mesopotâmica e sua forma de construir e perceber o mundo, muito se tem a dizer ainda sobre Inanna e seus vastos domínios.

Em suma, o culto a Inanna mostrou-se complexo e dinâmico ao longo do tempo, sobreviveu a mudanças profundas na sociedade mesopotâmica, adaptando-se ao contexto histórico vivido por seus fiéis, mas manteve características importantes de sua origem tribal.

Vinculada desde sempre ao inconsciente coletivo, essa divindade foi um arquétipo ${ }^{55}$ importante no universo religioso do Antigo Oriente Próximo e, ao desvelar um pouco sua personalidade das areias do tempo e do deserto, desvendamos também algumas formas de sexualidade sagrada amalgamadas na vida social e política daquelas culturas. Entendemos o porquê do seu epíteto de deusa da vida e das infinitas manifestações da vida.

Recebido em março de 2012. Aprovado em junho de 2012.

55 O vocábulo aqui tem duplo sentido e refere-se tanto ao sentido junguiano como ao utilizado por Eliade. 